\title{
Influence of Organic Loading Rates on Aerobic Granulation Process for the Treatment of Wastewater
}

\author{
B. K. Bindhu and G. Madhu
}

\begin{abstract}
Treatment of synthetic wastewater was studied with aerobic granulation technology in sequencing batch reactor under various organic loading rates (OLRs). Three trials (trial 1, 2, and 3) were conducted with OLRs of 3, 6, and 9 $\mathrm{kg}$ chemical oxygen demand $(\mathrm{COD}) /\left(\mathrm{m}^{3} . \mathrm{d}\right)$ respectively. Aerobic granules could be developed in all cases, but the best performance was observed with trial 2. A COD removal efficiency of $97.9 \%$ and sludge with good sludge volume index (SVI) of $25.1 \mathrm{ml} / \mathrm{g}$ could be achieved in trial 2 with OLR of $6 \mathrm{~kg}$ $\mathrm{COD} /\left(\mathrm{m}^{3} . \mathrm{d}\right)$. The maximum COD removal efficiency observed in trial 1 and trial 3 were $96 \%$ and $95 \%$ respectively. The minimum SVI obtained in trial 1 and trial 3 were 31 and 30.6 $\mathrm{ml} / \mathrm{g}$ respectively. During trial 3 , the reactor showed unhealthy conditions in terms of COD removal efficiency and SVI after 5 weeks of operation. This study contributes to a better understanding of the role of OLR in aerobic granulation.
\end{abstract}

Index Terms - Aerobic granulation, organic loading rate, sequencing batch reactor, sludge volume index.

\section{INTRODUCTION}

Biogranulation is a technology developed for wastewater treatment during early 80 's. During the initial period, research was intensive in the area of anaerobic granulation in upflow anaerobic sludge blanket (UASB) reactors [1]. Anaerobic granulation technology has been widely used for a wide variety of wastewaters. Still this technology has some drawbacks like a long start-up period, a relatively high operation temperature and unsuitability for low strength organic wastewater [2]. To overcome the above drawbacks, the research has been devoted to the development of aerobic granulation technology. Compared to conventional activated sludge flocs, the advantages of granular activated sludge are compactness and strength of the structure. It also has good settleability, high capacity for biomass retention and is able to withstand high organic loading rates.

Biogranulation involves cell-to-cell interactions in which biological, physical and chemical phenomena occur to form biogranules of spherical shape through self-immobilization of microorganisms. Aggregation of microorganisms is the most important activity in granule formation. It is a multi-step process in which many physical and biochemical factors play. Hence for the successful development of the aerobic granules, a number of conditions have to be met. Almost all research on

Manuscript received October 21, 2012; revised December 27, 2012. This work was supported in part by the Centre for Engineering Research and Development (CERD/2010/RSM-18), Trivandrum, Kerala.

B. K. Bindhu is with the Rajiv Gandhi Institute of Technology, Kottayam, Kerala, India (e-mail: bindhu@ rit.ac.in).

G. Madhu is with Cochin University of Science and Technology, Cochin, Kerala, India (e-mail: profmadhu@cusat.ac.in). aerobic granulation has been conducted and proved to be successful in sequencing batch reactors (SBRs), while no aerobic granulation has been reported in continuous reactors. A number of factors can influence the process of granulation. These include organic loading rate (OLR), seed sludge, substrate composition, settling time, hydrodynamic shear force, hydraulic retention time, volume exchange ratio, and reactor design.

Organic loading rate is a crucial factor in any biological treatment system in general and granulation process in particular. Anaerobic granulation in UASB is efficient under high organic loading rates. Many investigations have been done to understand the influence of OLR on the granulation process, still more light is to be thrown in this area. Formation and instability of aerobic granules were studied by Zheng et al. [3] with sucrose as the source of chemical oxygen demand (COD). This study deals with the influence of OLR on the pollutant removal efficiency and the reactor performance, when acetate is used as sole source of COD.

\section{MATERIALS AND METHODS}

\section{A. Experimental Set-up and Operation}

A column type SBR with an effective volume of 21 was used for the experiment. The internal diameter and the effective height of the reactor were $6.5 \mathrm{~cm}$ and $60.3 \mathrm{~cm}$ respectively. Influent was added from the bottom and the effluent was withdrawn from the middle port by two peristaltic pumps. The volume exchange ratio was kept as $50 \%$. Air was introduced from the bottom through a porous stone diffuser, maintaining a superficial air velocity of 3.0 $\mathrm{cm} / \mathrm{s}$. The reactor was operated in successive cycles of 4 hours, which is comprised of $5 \mathrm{~min}$ for feeding influent, 225 min for aeration, $5 \mathrm{~min}$ for settling, and $5 \mathrm{~min}$ for effluent withdrawal. The cyclic operation was controlled by a micro controller AT89C51. Schematic of the SBR is shown in Fig.1.

\section{B. Influent and Seed Sludge}

The synthetic wastewater consisted of sodium acetate as the sole carbon source was used for the study. The composition of the feeding solution including micro-nutriens was adopted from Tay et al. [4]. It gives a total COD of 2000 $\mathrm{mg} / \mathrm{l}$. The composition of the influent is given in Table I. Influents of COD concentrations $1000 \mathrm{mg} / \mathrm{l}, 2000 \mathrm{mg} / \mathrm{l}$, and $3000 \mathrm{mg} / \mathrm{l}$ were made for this study.

The seed sludge was collected from the activated sludge processing unit of the Petrochemical Division of Fertilizers And Chemicals Travancore (FACT) Limited, Cochin, Kerala. The sludge had a gray colour with sludge volume index (SVI) 
of $245 \mathrm{ml} / \mathrm{g}$ and mixed liquor suspended solids (MLSS) of $5050 \mathrm{mg} / \mathrm{l}$.

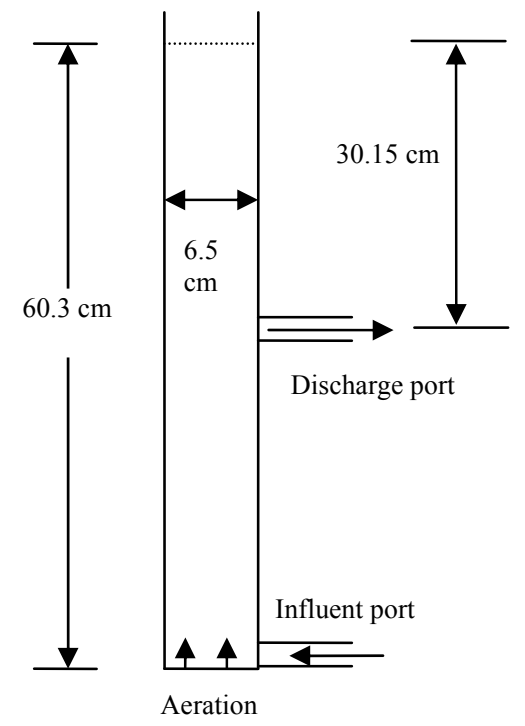

Fig. 1. Schematic of the Column SBR.

\begin{tabular}{lc}
\multicolumn{2}{c}{ TABLE I: COMPOSITION OF THE FEED } \\
\hline Constituent & Concentration \\
\hline Sodium acetate & $2.93 \mathrm{~g} / \mathrm{L}$ \\
$\mathrm{NH}_{4} \mathrm{Cl}$ & $350 \mathrm{mg} / \mathrm{L}$ \\
$\mathrm{K}_{2} \mathrm{HPO}_{4}$ & $30 \mathrm{mg} / \mathrm{L}$ \\
$\mathrm{KH}_{2} \mathrm{PO}_{4}$ & $25 \mathrm{mg} / \mathrm{L}$ \\
$\mathrm{CaCl}_{2} .2 \mathrm{H}_{2} \mathrm{O}$ & $30 \mathrm{mg} / \mathrm{L}$ \\
$\mathrm{MgSO}_{4} 7 \mathrm{H}_{2} \mathrm{O}$ & $25 \mathrm{mg} / \mathrm{L}$ \\
$\mathrm{FeSO}_{4} 7 \mathrm{H}_{2} \mathrm{O}$ & $20 \mathrm{mg} / \mathrm{L}$ \\
\hline \hline
\end{tabular}

Three OLRs were studied as 3, 6, and $9 \mathrm{~kg} \mathrm{COD} /\left(\mathrm{m}^{3} . \mathrm{d}\right)$ corresponding to influent COD concentrations of 1000, 2000, and $3000 \mathrm{mg} / \mathrm{l}$. All other operating parameters except influent COD concentration and hence OLR were kept constant for the present study. For each trial the reactor was started with $750 \mathrm{ml}$ of seed sludge.

\section{Analytical Methods}

Determination of COD, MLSS, mixed liquor volatile suspended solids (MLVSS) and SVI as per standard methods [5]. Samples from the reactor were collected and analyzed for $\mathrm{pH}, \mathrm{COD}, \mathrm{MLSS}$, and MLVSS daily and SVI on alternate days. $\mathrm{pH}$ and the dissolved oxygen (DO) concentration were monitored using a $\mathrm{pH}$ meter (Cyberscan $\mathrm{pH}-510)$ and DO meter (Cyberscan DO-110) respectively.

\section{RESUlTS AND DiscUSSION}

The reactor was seeded with the activated sludge taken from the wastewater treatment plant after 3 days acclimation. Aerobic granulation with three OLRs was studied. The variables in these trials are shown in Table II.

The reactor was put in operation, feeding with influent of COD concentration $\left(\mathrm{COD}_{\mathrm{i}}\right) 1000 \mathrm{mg} / \mathrm{l}$ with a resultant $\mathrm{OLR}$ of $3 \mathrm{~kg} \mathrm{COD} /\left(\mathrm{m}^{3} . \mathrm{d}\right)$ as trial 1 . High fluctuations in effluent $\mathrm{COD}\left(\mathrm{COD}_{\mathrm{e}}\right)$ were observed during the start-up period. After 20 days of operation, $\mathrm{COD}_{\mathrm{e}}$ was found to decrease at a steadier rate, making the percentage COD removal efficiency
$\left(\mathrm{COD}_{\mathrm{re}}\right)$ more than $80 \%$. Tiny granules were appeared in the reactor by $28^{\text {th }}$ day of operation. At this stage the settling of the sludge became faster. The granules slowly grew in size and reached an average size of $1.8 \mathrm{~mm}$. The reactor was operated for 45 days, in which the last 10 days showed a $\mathrm{COD}_{\text {re }}$ of $95 \%$ to $96 \%$. Hence the reaction was assumed to attain a steady state.

TABLE II: VARIABLE OPERATING PARAMETERS

\begin{tabular}{ccc}
\hline \hline Trial No & Influent COD $(\mathrm{mg} / \mathrm{l})$ & OLR $\left(\mathrm{kg} \mathrm{COD} /\left(\mathrm{m}^{3} . \mathrm{d}\right)\right)$ \\
\hline Trial 1 & 1000 & 3 \\
Trial 2 & 2000 & 6 \\
Trial 3 & 3000 & 9 \\
\hline \hline
\end{tabular}

In the trial 2, The reactor was fed with $\mathrm{COD}_{\mathrm{i}}$ of $2000 \mathrm{mg} / \mathrm{l}$ $\left(\mathrm{OLR}=6 \mathrm{~kg} \mathrm{COD} /\left(\mathrm{m}^{3} . \mathrm{d}\right)\right)$ and operated for 36 days. Steady conditions were achieved by around $28^{\text {th }}$ day and a better $\mathrm{COD}_{\text {re }}$ was also achieved (97.9\%) towards the end of operation. Appearance and development of the granules were at a faster rate with an average final size of $2.4 \mathrm{~mm}$. Trial 3 was conducted with $\mathrm{COD}_{\mathrm{i}}$ of $3000 \mathrm{mg} / \mathrm{l}(\mathrm{OLR}=9 \mathrm{~kg}$ $\left.\mathrm{COD} /\left(\mathrm{m}^{3} . \mathrm{d}\right)\right)$. Compared to the first two trials, trial 3 showed more fluctuations in $\mathrm{COD}_{\mathrm{e}}$, and hence in COD removal efficiency too. The granules were grown to a size of less than $1 \mathrm{~mm}$ only. The variations of $\mathrm{COD}_{\mathrm{e}}$ and $\mathrm{COD}$ removal efficiency were shown in Fig. 2 and Fig. 3 respectively.

The MLSS concentration of the seed sludge was 5050 $\mathrm{mg} / \mathrm{L}$. When the reactor was started with fresh influent, the MLSS concentration showed a slightly decreasing trend in all trials, and then gradually increased. These disturbances may be due to the struggle of the microorganisms to adjust with the new living conditions. The variations in MLSS in three trials are shown in Fig. 4. Towards the end of the operation, the trial with the highest OLR $\left(9 \mathrm{~kg} \mathrm{COD} /\left(\mathrm{m}^{3} . \mathrm{d}\right)\right)$, was found to be with unhealthy conditions of increasing trend of $\mathrm{COD}_{\mathrm{e}}$ and decreasing trend of MLSS concentration.

Sludge volume index is an important property to test the settleability of the sludge. Fluffy sludge has a small particle size and low density. Hence rate of settling will be low, resulting in a high SVI. The lower settling time provided in SBR, compared to that of conventional activated sludge process will eliminate very small suspended particles that are difficult to settle. Thus particles that can settle with in the allowed settling time will remain in the reactor, and particles with poor settleability will be washed out [6].

The SVI of the seed sludge was $245 \mathrm{ml} / \mathrm{g}$ and showed the presence of fluffy flocs. The SVI of the reactor contents in all the three trials showed a decreasing trend. Values of SVI greater than that of the seed sludge observed during the start-up period of the reactor may be due to the disturbances associated with some sludge washout. The minimum SVI observed were $31,25.1$, and $30.6 \mathrm{ml} / \mathrm{g}$ for trial 1,2 , and 3 respectively. But the settling nature of the sludge was deteriorated in trial 3 towards the last few days of the operation.

The OLR is an important operational parameter that can significantly influence the microbial ecology and process performance of aerobic granules systems [7]. Under an upward air velocity of $2.4 \mathrm{~cm} / \mathrm{s}$, stable operation was limited in the OLR range of $6.0-9.0 \mathrm{~kg} \mathrm{COD} /\left(\mathrm{m}^{3} . \mathrm{d}\right)$ and failed to 
operate with granule deterioration under further higher OLRs.

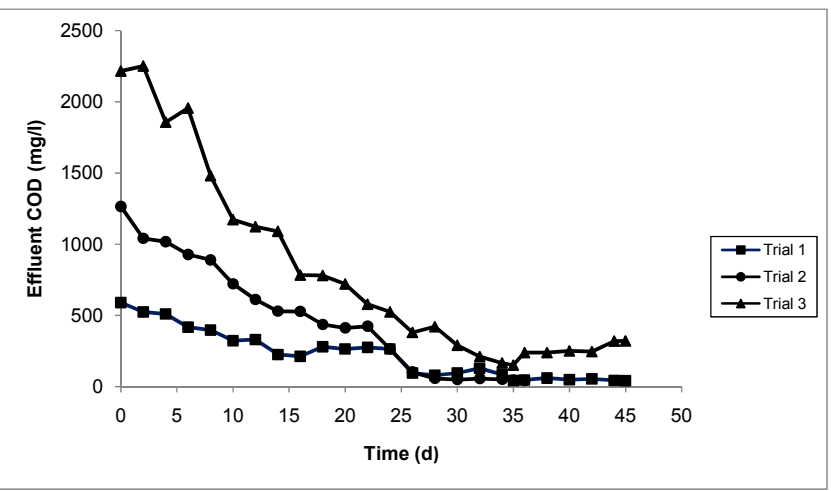

Fig. 2. Variation of effluent COD with time.

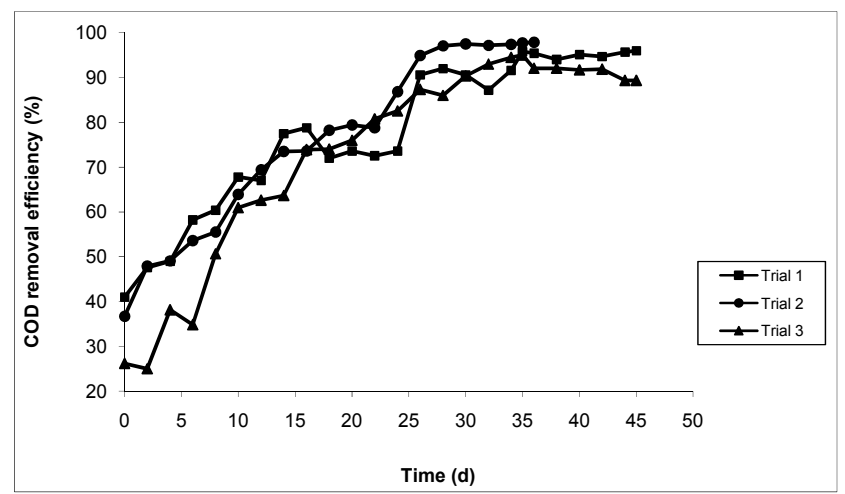

Fig. 3. Variation of COD removal efficiency with time.

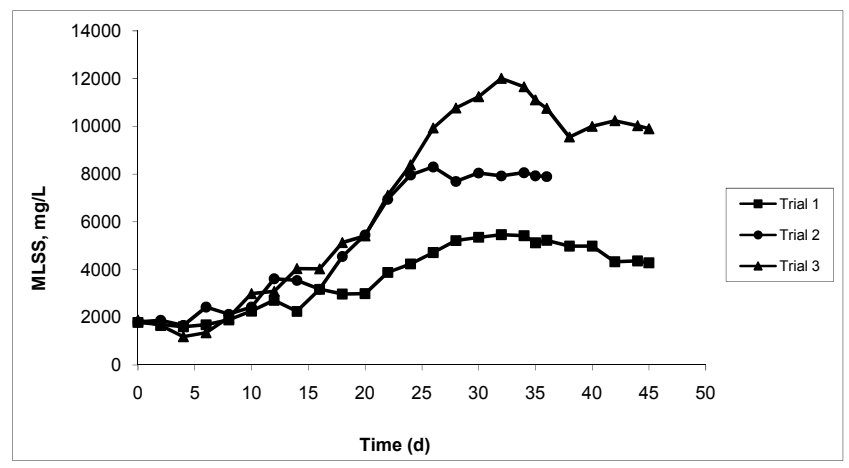

Fig. 4. Variation of MLSS with time

Tay et al. [8] studied the effect of OLR on the reactor performance and a moderate OLR was found to favour the development of stable aerobic granules. Liu et al. [9] also studied the effect of substrate concentration on the formation, structure, and characteristics of aerobic granules and observed that granules can be successfully formed with influent COD concentrations from 500 to $3000 \mathrm{mg} / \mathrm{l}$.

Enhancement strategies like use of some support materials can be adopted to yield a faster granulation. When Than et al. [10] used bivalve shell carrier as a support material for aerobic granulation, granular sludge with SVI as low as $15 \pm 1$ $\mathrm{ml} / \mathrm{g}$ was obtained even at an OLR of $15 \mathrm{~kg} \mathrm{COD} /\left(\mathrm{m}^{3} . \mathrm{d}\right)$. In the present study best performance in terms of COD removal $(97.9 \%)$ and sludge settleability (SVI of $25.1 \mathrm{ml} / \mathrm{g}$ ) was observed in trial 2 with OLR of $6 \mathrm{~kg} \mathrm{COD} /\left(\mathrm{m}^{3} . \mathrm{d}\right)$.

Aerobic granular technology has been successfully applied by Moy et al. [11] for the treatment of high strength organic wastewater between the OLRs of 6 and $15 \mathrm{~kg} \mathrm{COD} /\left(\mathrm{m}^{3} . \mathrm{d}\right)$, being the OLRs increased gradually. Apart from synthetic wastewaters, real wastewaters like dairy effluents were also subjected to treatment by aerobic granulation successfully with a COD removal efficiency of $90 \%$ [12].

\section{ACKNOWLEDGMENT}

The authors wish to acknowledge the financial support from Centre for Engineering Research and Development (CERD/2010/RSM 18), Trivandrum, Kerala.

\section{REFERENCES}

[1] J. E. Schmidt and B. K. Ahring, "Granular sludge formation in upflow anaerobic sludge blanket (UASB) reactor," Biotechnol Bioeng., vol. 49, no. 3, pp. 229-246, 1996.

[2] E. Morgenroth, T. Sherden, M. C. M van Loosdrecht, J. J. Heijnen, and P. A. Wilderer, "Aerobic granular sludge in a sequencing batch reactor," Water Res., vol. 31, no. 12, pp. 3191-3194, 1997.

[3] Y. M. Zheng, H. Q. Yu, S. J. Liu, and X. Z. Liu, "Formation and instability of aerobic granules under high organic loading conditions," Chemosphere, vol. 63, pp. 1791-1800, 2006.

[4] J. H. Tay, Q. S. Liu, and Y. Liu, "Aerobic granulation in sequential sludge blanket reactor," Water Science and Technology, vol. 46, no. 4-5, pp. 13-18, 2002.

[5] Standard Methods for the Examination of Water and Wastewater, $19^{\text {th }}$ ed. American Public Health Association, Washington DC, 1995.

[6] L. Qin and Y. Liu, "Aerobic granulation at different settling times," in Wastewater Purification, Y. Liu, Ed. CRC Press, 2008, ch. 4, pp. 51-52.

[7] Y. Chen, W. Jiang, D. T. Liang, and J. H. Tay, "Aerobic granulation under the combined hydraulic and loading selection pressures," Bioresource Technology, vol. 99, pp. 7444-7449, 2008.

[8] J. H. Tay, S. Pan, Y. X. He, and S. T. L. Tay, "Effect of organic loading rate on aerobic granulation: Part I. Reactor performance," Environ. Eng., vol. 130, pp. 1094-1101, 2004.

[9] Q. S. Liu, J. H. Tay, and Y. Liu, "Substrate concentration-independent aerobic granulation in sequential aerobic sludge blanket reactor," Environ. Technol., vol. 24, pp. 1235-1242, 2003.

[10] B. X. Thanh, C. Visvanathan, and R. B. Aim, "Characterization of aerobic granular sludge at various organic loading rates," Process Biochemistry, vol. 44, pp. 242-245, 2009.

[11] B. Y .P. Moy, J. H. Tay, S. K. Toh, Y. Liu, and S. T. L. Tay, "High organic loading influences the physical characteristics of aerobic sludge granules," Lett Appl Microbiol, vol. 34, pp. 407-12, 2002.

[12] N. Schwarzenbeck, J. M. Borges, and P. A. Wilderer, "Treatment of dairy effluents in an aerobic granular sludge sequencing batch reactor," Applied Microbiol Biotechnol, vol. 66, pp. 711-718, 2005.

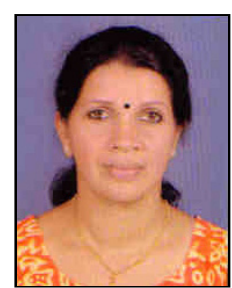

B. K. Bindhu was born in Kottayam, on April 24, 1968. She received B.Tech in Civil Engineering from Mahatma Gandhi University, Kottayam, Kerala, India in 1990, MSc in Environmental Studies from Cochin University of Science and Technology, Cochin, Kerala, India in 1993 and M.Tech in Environmental Engineering from Indian Institute of Technology Madras (IITM), Chennai, Tamil Nadu, India in 2005.

She worked as LECTURER for more than 2 years in the School of Environmental Studies, Mahatma Gandhi University, Kerala. She has been working as the ASSISTANT PROFESSOR in Department of Civil Engineering of Rajiv Gandhi Institute of Technology, Kottaym, Kerala, India for the past 12 years. Her areas of interest are the biological treatment of wastewater and solid waste and environmental impact assessment. She worked in the anaerobic degradation of kitchen waste and published a paper on "Effect of phase separation on anaerobic digestion of kitchen waste" [J. Environ. Eng. Sci. vol. 7, pp. 91-103, 2007]. Currently she is working in the aerobic treatment of wastewater.

Ms. Bindhu is a life member of Indian Society of Technical Education (ISTE). 